\title{
Endocrine manifestations in a cohort of 63 adulthood and childhood onset patients with Langerhans cell histiocytosis
}

\author{
Yempabou Sagna ${ }^{1,2}$, Carine Courtillot ${ }^{2}$, Joseph Y Drabo', Abdellatif Tazi' ${ }^{3}$, Jean Donadieu ${ }^{4}$, Ahmed Idbaih ${ }^{5}$, \\ Fleur Cohen ${ }^{6}$, Zahir Amoura ${ }^{6}$, Julien Haroche ${ }^{6}$ and Philippe Touraine ${ }^{2}$ \\ 'Service de Médecine Interne, CHU Yalgado Ouedraogo, UFR Sciences de la Santé, Université Ouaga I Pr Joseph Ki Zerbo, \\ Ouagadougou, Burkina Faso, ${ }^{2}$ Service d'Endocrinologie et Médecine de la Reproduction, Hôpital Universitaire Pitié Salpêtrière - Charles \\ Foix, Sorbonne Université, Faculté de Médecine, Paris, France, ${ }^{3}$ Service de Pneumologie, Centre National de Référence des \\ Histiocytoses, Hôpital Saint-Louis, Equipe de Recherche en Biostatistiques et Epidémiologie Clinique, U1153 CRESS, Univ Paris Diderot, \\ Sorbonne Paris Cité, Paris, France, ${ }^{4}$ Service d'Hémato-Oncologie Pédiatrique, Hôpital Trousseau, Paris, France, \\ ${ }^{5}$ Sorbonne Université, Inserm, CNRS, UMR S 1127, Institut du Cerveau et de la Moelle épinière, ICM, AP-HP, Hôpitaux \\ Universitaires La Pitié Salpêtrière - Charles Foix, Service de Neurologie 2-Mazarin, Paris, France, and ${ }^{6}$ Service de \\ Médecine Interne, Hôpital Universitaire Pitié Salpêtrière - Charles Foix, Sorbonne Université, Faculté de Médecine, \\ Paris, France \\ Correspondence \\ should be addressed \\ to P Touraine \\ Email \\ philippe.touraine@aphp.fr
}

\begin{abstract}
Objective: Langerhans cell histiocytosis $(\mathrm{LCH})$ is a rare inflammatory myeloid neoplasm which can infiltrate any organ or tissue. Endocrine involvement has mostly been described in case reports and small retrospective studies. We aimed to describe endocrine manifestations in a large cohort of adulthood onset (AO) and childhood onset (CO) patients with LCH.

Design: Single-center observational study conducted between January 2002 and December 2017 at Pitié-Salpêtrière University Hospital (Paris, France), a tertiary care hospital.

Method: Clinical, biological and morphological evaluations of pituitary, gonadal, adrenal and thyroid function evaluations performed in 63 consecutive patients with LCH (AO patients: 40, CO patients: 23). Fifty-eight patients underwent follow-up assessments.

Results: Complete pituitary evaluation was performed in 38/63 patients (60.3\%); at least one anterior pituitary dysfunction (APD) was found in $63.2 \%$ of them. In this subgroup of patients, the most prevalent deficiencies were diabetes insipidus (DI) and GHD (55.3\% each), followed by gonadotropin deficiency (34.2\%) and thyrotropin deficiency (23.7\%). In the subgroup of the 25 incompletely evaluated patients, we found DI in $44 \%$, GHD in 50\%, gonadotropin deficiency in $30.4 \%$ and thyrotropin deficiency in $16 \%$. APD was more common in CO patients $(P=0.003)$ but was not systematically associated with DI regardless of the age of onset. Endocrine dysfunction was most often permanent; moreover, occurrence of new deficiencies has been described during follow-up.

Conclusion: The spectrum of endocrine disorders appears to be large in LCH (both in AO and CO patients) and should be evaluated carefully at diagnosis and during follow-up. APD was not always associated with DI.
\end{abstract}

European Journal of Endocrinology

(2019) 181, 275-285
Published by Bioscientifica Ltd. 


\section{Introduction}

Langerhans cell histiocytosis (LCH) is a rare inflammatory myeloid neoplasm that can infiltrate any organ or tissue of the body (1). It is the most common histiocytic disorder, characterized by CD1a and/or Langerin (CD207)-positive cells on immunostaining that are required for definitive diagnosis $(2,3)$. Its pathogenesis is still not precisely defined; a clonal component along with a frequent BRAFV600E mutation have been identified, indicating that LCH is a disorder that is more neoplastic than reactive (3).

Initially described in childhood onset (CO) disease, it is now increasingly recognized in AO cases.

The clinical presentations of LCH vary from clinically self-limiting lesions that resolve spontaneously to rapidly progressive disease that requires systemic chemotherapy. Any organ or system of the human body can be affected, but those most commonly involved in children are bones (80\% of cases), skin (33\%), pituitary gland $(25 \%)$, liver, spleen, hematopoietic system and lungs (15\% each), lymph nodes (5-10\%) and central nervous system excluding the pituitary gland (2-4\%). In adult patients, the lungs are most commonly affected $(4,5,6)$.

The current classification differentiates between lung LCH or single system LCH (SS-LCH: only one organ or system is involved, such as one or more bones, skin, lymph nodes, the hypothalamic-pituitary/central nervous system, lungs in adults) and multisystem disease (MS-LCH: two or more organs or systems are involved, with or without involvement of risk organs) (7).

Treatment options vary depending on the extent of the disease and the severity at onset. The current standard of care, based on LCH III, is 1 year of therapy with vinblastine and prednisone, plus mercaptopurine for patients with high-risk disease (8).

Endocrine manifestations have been described in $\mathrm{LCH}$ in a few case reports and in small retrospective $\mathrm{AO}$ series $(9,10)$. In 2016, the French national CO LCH patients registry had 1478 patients, of whom 223 (15\%) had an endocrine manifestation, though evaluations were only done when there was a suspected endocrine abnormality (11). Infiltration of the hypothalamo-pituitary axis leading to diabetes insipidus (DI) is the main known endocrine symptom of LCH in about $15-25 \%$ of CO and $12-30 \%$ of AO patients. Anterior pituitary dysfunction is found in up to $20 \%$ of patients with $\mathrm{LCH}$ and is almost always associated with DI. Growth hormone $(\mathrm{GH})$ deficiency is the most common anterior pituitary hormone deficiency, followed by adrenocorticotropin (ACTH) deficiency, thyroid-stimulating hormone (TSH) deficiency and hyperprolactinemia (9).

There seems to be no information about the prevalence of bone metabolism disorders in AO disease, but there are several predisposing factors, such as inflammatory cytokines, anterior pituitary hormone deficiencies and treatment with glucocorticoids in particular.

To date, no comprehensive investigation of the endocrine manifestations has been conducted in a large cohort study. We thus decided to perform hormonal evaluations on all consecutive patients diagnosed with LCH with or without known endocrine dysfunction (ED) referred to our department. Our aims were to determine the prevalence of endocrine manifestations in $\mathrm{LCH}$ and to describe their evolution during follow-up.

We present 15 years of experience from this first single-center study evaluating the endocrine features of $\mathrm{AO}$ and $\mathrm{CO} \mathrm{LCH}$ in our cohort.

\section{Patients and methods}

This was a single-center observational study conducted from January 2002 to December 2017 and included all patients (CO and $\mathrm{AO}$ ) diagnosed with $\mathrm{LCH}$ at La PitiéSalpêtrière-Charles Foix University Hospital (Paris, France). Patients could have been managed in the department of endocrinology or those of internal medicine and neurology.

We first listed all patients followed for histiocytosis disorder. Then, based on histological proof and/or typical lesions, we excluded the other types of histiocytosis to include only LCH (Fig. 1). Most CO LCH patients were received as part of transition to adult health care and had already some known ED. The distinction between CO and AO was made using the age of first signs of $\mathrm{LCH}$, with a cut-off age of 18 years.

An endocrine evaluation was proposed for all consecutive patients in the department of endocrinology and reproductive medicine. Those in whom this was not possible underwent an endocrine evaluation in the internal medicine department or in the department of neurology. Patients in the internal medicine and/or neurology and/or endocrinology and reproductive medicine departments had endocrine reevaluations during follow-up. Data were collected retrospectively and we only reported evaluations done in these departments. We distinguished our patients in two subgroups, one with patients with complete endocrine evaluation and the other one including patients with incomplete endocrine evaluation. 


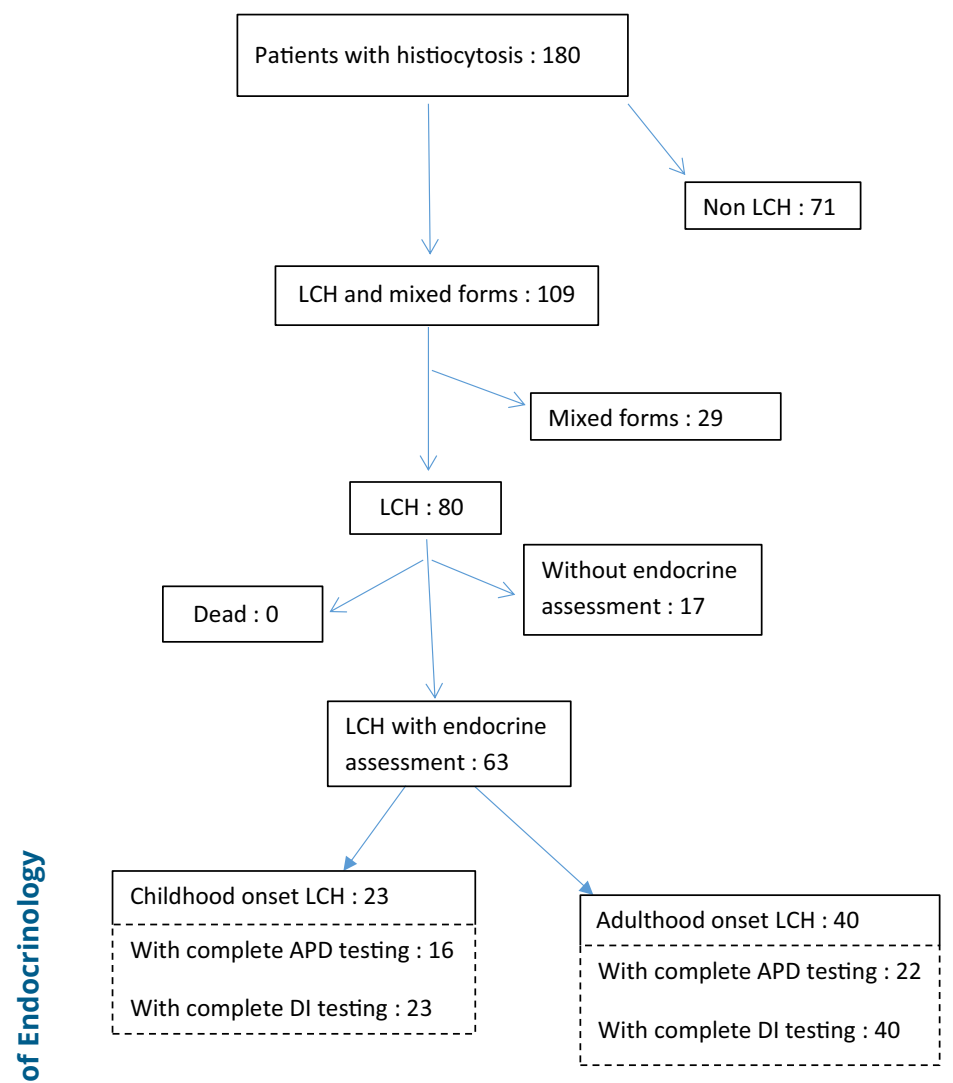

\section{Figure 1}

Flow chart to indicate how subjects were selected for inclusion in the study. APD, anterior pituitary deficiency; DI, diabetes insipidus; LCH, Langerhans cell histiocytosis.

\section{Data collection}

Data were collected from hospital patient medical records.

The following data were recorded: age at diagnosis of LCH and age at first clinical signs, age at first endocrine signs, endocrine involvement known before the assessment.

Clinical examination data included, 24-h evaluation of water intake and diuresis, thyroid examination and breast and genital examination.

Hormonal assays were performed to explore pituitary and peripheral gland function as follows:

- Patients were considered to have DI if they were already being treated with desmopressin or if they had a polyuria-polydipsia syndrome responding to desmopressin treatment following a water deprivation test (12).

- Gonadotropin and gonadal functions were evaluated based on FSH and LH in all patients, estradiol (E2), in women and total testosterone in men.
Central hypogonadism was defined in men by the presence of low testosterone levels with the absence of increased gonadotropins. In premenopausal females the diagnosis of central hypogonadism was defined by the presence of oligomenorrhea/amenorrhea (after exclusion of other causes of menstrual irregularity) in addition to low estrogens and gonadotropin levels. In postmenopausal women, the absence of high serum FSH and LH was sufficient for a diagnosis of gonadotropin dysfunction (13).

- Thyrotropin function and thyroid function were evaluated based on the TSH, free T4, free T3 and antithyroid peroxidase (ATPO) and antithyroglobulin (ATG) antibody concentrations. Central hypothyroidism was characterized by an FT4 level below the laboratory reference range in conjunction with a low, normal or mildly elevated TSH (13).

- Lactotropin function was evaluated based on prolactin (PRL) concentration. Hyperprolactinemia was defined when PRL was $>25 \mu \mathrm{g} / \mathrm{L}$ in women and $>20 \mu \mathrm{g} / \mathrm{L}$ in men (14).

- Corticotropin insufficiency was defined by a plasma cortisol level of $<3 \mu \mathrm{g} / \mathrm{dL}$, a response to an insulin tolerance test (ITT) or $0.25 \mathrm{mg}$ of Synacthen of $<18 \mu \mathrm{g} / \mathrm{dL}$ for plasma cortisol and $<1.3 \mu \mathrm{g} / \mathrm{dL}$ for salivary cortisol, associated with normal or low ACTH. Adrenal glucocorticoid insufficiency was defined by the same thresholds for cortisol as those associated with elevated ACTH $(15,16)$.

- Somatotropin function was evaluated based only on the IGF-I and GH concentrations under stimulation by an ITT, when possible. According to guidelines (13, 17, $18,19)$, GH deficiency (GHD) was defined in adults by a peak $\mathrm{GH}$ concentration $<5 \mu \mathrm{g} / \mathrm{L}$ after a stimulation test (severe GHD was defined as a peak GH concentration of $<3 \mu \mathrm{g} / \mathrm{L}$, and partial GHD was defined as a peak GH concentration between 3 and $5 \mu \mathrm{g} / \mathrm{L})$. In children, a GH peak concentration below $4 \mu \mathrm{g} / \mathrm{L}(5 \mu \mathrm{g} / \mathrm{L}$ in transition period) defined complete GHD and a peak between 4 and $7 \mu \mathrm{g} / \mathrm{L}$ indicated partial GHD $(20,21,22,23)$. A second $\mathrm{GH}$ stimulation test was not performed to confirm diagnosis when GHD was isolated. The IGF-I concentrations was evaluated using normal age-related reference concentrations (24).

Bone metabolism was assessed based on the serum calcium, serum phosphorus, PTH1-84 and 25-hydroxyvitamin D concentrations.

The following radiological examinations were performed: pituitary magnetic resonance imaging 
(MRI), pelvic ultrasound, thyroid ultrasound and bone mineral density (BMD) assessment by dual-energy X-ray absorptiometry (DEXA). In postmenopausal women and in men aged 50 and older, osteoporosis was diagnosed if the T-score of the lumbar spine, total hip or femoral neck was -2.5 or less. In females prior to menopause and in males younger than age 50 years, a Z-score of -2.0 or lower was defined as 'below the expected range for age,' and a Z-score above -2.0 was 'within the expected range for age' (25).

\section{Assay methods}

Blood tests were performed at $08: 00 \mathrm{~h}$, and hormonal assays were processed in the biochemical and hormonal department of Pitié-Salpêtrière Hospital. FSH, LH, E2, progesterone, total testosterone, prolactin, ACTH, plasma cortisol, TSH, T4L, T3L and PTH (1-84) were measured according to the Modular E170 chemiluminescence method (Roche Diagnostics). In patients with hyperprolactinemia, we used polyethylene glycol precipitation to detect macroprolactinemia. GH, IGF1, aldosterone, renin and $25-\mathrm{OH}$ vitamin $\mathrm{D}$ were measured by a chemiluminescence method (Liaison XL Diasorin, Vercelli, Italy). D-4 androstenedione was measured by an extraction method+RIA IM0674 (Beckman Coulter), DHEA-S was measured by chemiluminescence (Access, Beckman Coulter), ATG and ATPO antibodies were measured by Phadia 250 EliA.

\section{Ethical consideration}

This is a retrospective observational study. By French law, no IRB advice was required to conduct this study.

\section{Statistical analysis}

Continuous variables are expressed as a mean \pm standard deviation (s.D.) and compared by Student's unpaired, twosided $t$-test.

Categorical variables are presented as percentages and compared using the chi-square $\left(\chi^{2}\right)$ test or the Fisher's exact test.

All reported $P$ values are two-sided. $P$ values $<0.05$ were considered statistically significant.

The statistical analyses were performed using Predictive Analytics Software (PASW Statistics) version 18.

\section{Results}

From January 2002 to December 2017, 63 patients (40 AO with 15 males and $23 \mathrm{CO}$ with 12 males) with $\mathrm{LCH}$ were followed at Pitié-Salpêtrière hospital with endocrine assessments (Fig. 1). Seventeen patients followed in the department of neurology had no endocrine assessment and were excluded from the study.

All of the 63 included patients did not have a complete endocrine evaluation for many reasons:

- concerning corticotropin function, it was not evaluated in five patients under treatment with corticosteroids for $\mathrm{LCH}$ at the time,

- concerning gonadotropin function, prolactinemia, GH stimulation test, we did not obtain data respectively in 2, 4 and 23 patients, mainly because of the management of those patients in departments with lower practice of endocrinological tests.

Complete anterior pituitary evaluation was obtained in 38 patients $(60.3 \%)$.

The baseline characteristics of all patients with $\mathrm{LCH}$ are summarized in Table 1 . The mean time between the first clinical signs and the diagnosis of $\mathrm{LCH}$ was 1.7 years for $\mathrm{AO}$ and 1.6 years for $\mathrm{CO}$ patients. Eighteen of the 40 AO patients and 14 of the 23 CO patients had MS-LCH.

The BRAF status was evaluated for LCH lesions in 14 patients $(22.2 \%)$ and a BRAFV600E mutation was identified in 3 cases (21.4\%).

Twelve of the $40 \mathrm{AO}$ patients and 18 of the $23 \mathrm{CO}$ patients had known ED before evaluation $(P=0.006)$; this mostly concerned DI in 27 patients.

\section{Pituitary and peripheral gland function}

Considering the 38 patients with complete evaluation, 24 patients $(63.2 \%$, including $50 \%$ of $\mathrm{AO} \mathrm{LCH}$ and $81.2 \%$ of $\mathrm{CO}$ forms) had at least one anterior pituitary dysfunction (APD, Table 2): 8 (22.2\%) had 2 APDs, 5 (13.9\%) had 3 APDs and 5 others (13.9\%) had 4 APDs. In this subgroup, an ED was the first sign of LCH in $36.8 \%$ patients (14 of 38 ). Overall, the first ED was DI in $47.4 \%$ of patients (18 of 38 ), growth deficiency in $13.2 \%$ (5 of 38 ), gonadotropin deficiency, hyperprolactinemia and thyrotropin deficiency in $2.6 \%$ each $(1 / 38)$.

For the other 25 patients, 12 (48\%) had at least one APD (Table 2). Among them, an ED was the first sign of LCH in $12 \%$ patients (3 of 25); and the first endocrine dysfunction was DI in $36 \%$ of patients (9 of 25), 
Table 1 Baseline characteristics of patients with LCH at their first endocrine evaluation.

\begin{tabular}{l}
\hline \\
Age at diagnosis, years (median/min-max) \\
Origin \\
Caucasian \\
Unknown \\
Afro-American \\
Age at first clinical signs of LCH, years (median/min-max) \\
Time before diagnosis, years (mean/min-max) \\
Type of LCH (\%) \\
Single systemic LCH \\
Multisystemic LCH \\
Type of involvement (\%) \\
Skeletal \\
Unifocal \\
Multifocal \\
Pulmonary \\
Cutaneous \\
Mucous \\
Central nervous system ${ }^{* *}$ \\
Hematological \\
Lymph node \\
Hepatic \\
Intestinal \\
Histological proof of LCH (\%) \\
BRAF status performed (\%) \\
Positive \\
LCH disease activity at the time of endocrine evaluation \\
Non-active disease \\
Stable disease \\
Regressive disease \\
Progressive disease \\
Toxics \\
Tobacco \\
Alcohol \\
\end{tabular}

*All genital, ${ }^{* *}$ other than hypothalamo-pituitary involvement.

gonadotropin deficiency in $4.3 \%$ ( 1 of 23 ) and hyperprolactinemia in $4.8 \%$ each ( 1 of 21 ).

We thus found ED in nine patients who had no suspected endocrine abnormality: 6 in the 38 completely evaluated patients $(15.8 \%)$ and 3 in the 25 others (12\%).

\section{Diabetes insipidus}

DI was found in 21 of the 38 completely evaluated patients (55.3\%) and in 11 of the 25 others (44\%). It was more significantly found in $\mathrm{CO}$ than AO disease $(P=0.006)$. It was found in 13 of the 31 patients (41.9\%) with SS-LCH and 19 of the 32 patients (59.4\%) with MS-LCH, but this difference was not significant $(P=0.26)$.

\section{Somatotropin function}

A GH stimulation test by ITT was performed in 40 patients.

\begin{tabular}{|c|c|c|}
\hline Adulthood onset & Childhood onset & $P$ value \\
\hline $34(19,87)$ & $4(0,23)$ & - \\
\hline 9 & 6 & - \\
\hline 30 & 16 & - \\
\hline 1 & 1 & - \\
\hline $32.5(18-87)$ & $4(0-17)$ & - \\
\hline $1.7(0-12)$ & $1.6(0-12)$ & - \\
\hline $22 / 40(55)$ & 9/23 (39.1) & 0.341 \\
\hline $18 / 40(45)$ & $14 / 23$ (60.9) & 0.341 \\
\hline $24 / 40(60)$ & $15 / 23(65.2)$ & 0.887 \\
\hline $15 / 24(62.5)$ & $9 / 15(60)$ & 0.878 \\
\hline 9/24 (37.5) & 6/15 (30) & 0.878 \\
\hline $20 / 40(50)$ & 9/23 (39.1) & 0.421 \\
\hline $9 / 40(22.5)$ & $11 / 23(47.8)$ & 0.046 \\
\hline $3 / 40(7.5)^{*}$ & $0 / 23$ & 0.293 \\
\hline $3 / 40(7.5)$ & $9 / 23(39.1)$ & 0.005 \\
\hline $0 / 40$ & $3 / 23(13)$ & 0.045 \\
\hline $2 / 40(5)$ & $0 / 23$ & 0.529 \\
\hline $0 / 40$ & $3 / 23(13)$ & 0.045 \\
\hline $2 / 40(5)$ & $0 / 23$ & 0.529 \\
\hline $39 / 40$ (97.5) & $23 / 23(100)$ & - \\
\hline $9 / 40(22.5)$ & 5/23 (21.7) & - \\
\hline $1 / 9(11.1)$ & $2 / 5(40)$ & - \\
\hline $20 / 40(50)$ & $9 / 23(39.1)$ & 0.568 \\
\hline $9 / 40(22.5)$ & $2 / 23(8.7)$ & 0.301 \\
\hline $5 / 40(12.5)$ & $10 / 23(43.5)$ & 0.013 \\
\hline $6 / 40(15)$ & 2/23 (8.7) & 0.699 \\
\hline $25 / 40(62.5)$ & $13 / 23(56.5)$ & 0.841 \\
\hline $2 / 40(5)$ & $3 / 23(13)$ & 0.345 \\
\hline
\end{tabular}

It revealed GHD in 21 of the 38 completely evaluated patients (55.3\%) and 1 among the 2 other patients; the frequency was not different between $\mathrm{CO}$ and $\mathrm{AO}$ disease $(P=0.1)$. Four of the GHD adult patients were obese.

The IGF-I level was evaluated in all the 38 completely evaluated patients and 13 of them (34.2\%) had a level $<-2$ SD. It was also evaluated in 15 of the other patients in whom 3 (20\%) had a level <-2 SD.

All the 22 patients with GHD had an IGF-I level $<-1$ SD and 13 of them had a level <-2 SD.

\section{Corticotropin function}

The pituitary-adrenal axis was evaluated in 58 patients and was normal in $81 \%$ of them. Corticotropin deficiency was found in 8 of the 38 completely evaluated patients (21\%) and 3 in the 20 others (15\%), all with a history of 
Table 2 Frequency of endocrine dysfunctions in patients with LCH.

\begin{tabular}{|c|c|c|c|}
\hline \multirow[b]{2}{*}{ Hormonal dysfunction } & \multicolumn{2}{|c|}{$\%$ of patients $(n / N)$} & \multirow[b]{2}{*}{$P$ value } \\
\hline & Adulthood & Childhood & \\
\hline Age at first endocrine signs, years (median/min-max) & $31.5(18-58)$ & $6(2-23)$ & - \\
\hline Age at first endocrine evaluation, years (median/min-max) & $39(20-88)$ & $20^{*}(14-62)$ & - \\
\hline Known endocrine dysfunction before evaluation & $12 / 40(30)$ & $18 / 23(78.3)$ & 0.000 \\
\hline DI & $10 / 40(25)$ & $17 / 23(73.9)$ & 0.000 \\
\hline At least 1 APD & $7 / 40(17.5)$ & $13 / 23(56.5)$ & 0.003 \\
\hline At least 1 APD without DI & $1 / 40(2.5)$ & $1 / 23(4.3)$ & 0.730 \\
\hline Patients with complete evaluation & $55(22 / 40)$ & $69.6(16 / 23)$ & - \\
\hline Endocrine dysfunction & $50(11 / 22)$ & $93.7(15 / 16)$ & 0.005 \\
\hline Diabetes insipidus & $36.4(8 / 22)$ & $81.2(13 / 16)$ & 0.008 \\
\hline At least 1 APD & $50(11 / 22)$ & $81.2(13 / 16)$ & 0.08 \\
\hline GH deficiency & $45.4(10 / 22)$ & $81.2(11 / 16)$ & 0.2 \\
\hline Partial & $40(4 / 10)$ & $27.3(3 / 11)$ & 0.659 \\
\hline Severe & $60(6 / 10)$ & $72.7(8 / 11)$ & 0.659 \\
\hline Hyperprolactinemia & $22.7(5 / 22)$ & $18.7(3 / 16)$ & 0.546 \\
\hline Gonadotropin deficiency & $31.8(7 / 22)$ & $37.5(6 / 16)$ & 0.746 \\
\hline Central deficiency & $100(7 / 7)$ & $100(6 / 6)$ & - \\
\hline TSH deficiency & $18.2(4 / 22)$ & $31.2(5 / 16)$ & 0.449 \\
\hline Corticotropin deficiency & $13.6(3 / 22)$ & $31.2(5 / 16)^{\star *}$ & 0.243 \\
\hline Patients with incomplete evaluation & $45(18 / 40)$ & $30.4(7 / 23)$ & - \\
\hline Endocrine dysfunction & $50(9 / 18)$ & $71.4(5 / 7)$ & 0.406 \\
\hline Diabetes insipidus & $38.9(7 / 18)$ & $57.1(4 / 7)$ & 0.656 \\
\hline At least 1 APD & $38.9(7 / 18)$ & $71.4(5 / 7)$ & 0.201 \\
\hline GH deficiency & NA & $50(1 / 2)^{\star \star \star}$ & - \\
\hline Hyperprolactinemia & $25(4 / 16)$ & $20(1 / 5)$ & 0.948 \\
\hline Gonadotropin deficiency & $25(4 / 16)$ & $42.8(3 / 7)$ & 0.625 \\
\hline Central deficiency & $75(3 / 4)$ & $100(3 / 3)$ & - \\
\hline Peripheral deficiency & $25(1 / 4)$ & 0 & - \\
\hline TSH deficiency & 0 & $57.1(4 / 7)$ & 0.062 \\
\hline Corticotropin deficiency & $7.1(1 / 14)$ & $33.3(2 / 6)^{* \star}$ & 0.201 \\
\hline
\end{tabular}

*Some of them had undertaking endocrine evaluations in childhood but here we just consider evaluations done in our department, ${ }^{* *}$ all after corticotherapy, ${ }^{* * *}$ complete GHD.

APD, anterior pituitary dysfunction; DI, diabetes insipidus; GH, growth hormone; NA, non-applicable, none was evaluated; TSH, thyroid-stimulating hormone.

corticosteroid treatment. No patient showed the features of adrenal glucocorticoid insufficiency.

\section{Gonadotropin function}

We found gonadotropin deficiency in 13 of 38 completely evaluated patients $(34.2 \%)$, and in 7 of the 23 others (30.4\%) with no difference between the CO and AO forms $(P=0.56)$. We found a history of delayed puberty in five CO.

Eight women were postmenopausal. Among the 28 premenopausal women, 10 had regular menses, 11 had amenorrhea and the 7 other women had oligomenorrhea. Hormonal evaluation showed that the pituitary-gonadal axis was normal in $61.1 \%$ of the women. There was a gonadotropin deficiency in 7 of 23 completely evaluated women (30.4\%, including 1 postmenopausal) and in 6 of the 12 others $(50 \%)$.

We found one idiopathic ovarian insufficiency (46 XX, no anti-ovarian antibodies and no fragile $\mathrm{X}$ abnormality) diagnosed at the age of 37 years and before the diagnosis of LCH. Pelvic ultrasounds were performed in 13 women and showed no abnormalities (in particular, no ovarian infiltration aside from one ovarian endometriosis).

In male patients, decreased libido was mentioned in $11.5 \%$ (3 of 26, all AO patients) and there was no erectile dysfunction. The hormonal evaluation showed gonadotropin deficiency in $40 \%$ of the completely evaluated men (6 of 15; 2 had decreased libido) and in $9.1 \%$ of the others ( 1 of 11 ); we did not find any testicular deficiency. There was no clinical testicular abnormality. Testicular ultrasounds were performed in five men and showed no abnormalities (in particular, no testicular infiltration).

\section{Serum prolactin}

Hyperprolactinemia was found in $21 \%$ of the completely evaluated patients ( 8 of 38) (Table 2), respectively $24 \%$ in 
women and $18.5 \%$ in men. It was found in 5 of the 21 other patients $(23.8 \%)$.

The PRL elevation was very mild in all patients: the mean PRL level in men was $31.7 \pm 12 \mathrm{ng} / \mathrm{mL}$ and $32.3 \pm 10.8 \mathrm{ng} / \mathrm{mL}$ in women. No use of treatments that induce hyperprolactinemia was reported. One woman had galactorrhea on the clinical examination. One man had bilateral gynecomastia with normal serum prolactin and two women had galactorrhea on the clinical examination.

\section{Thyrotropin function}

Nine of the 38 completely evaluated patients $(23.7 \%)$ and 4 of the 25 others (16\%) had thyrotropin deficiency (Table 2). It was more frequent in the $\mathrm{CO}$ form than in $\mathrm{AO}$ disease $(P=0.016)$. Six patients had primary autoimmune hypothyroidism before the diagnosis of $\mathrm{LCH}$ and one other underwent a total thyroidectomy for a multinodular goiter (we excluded these patients from the thyroid evaluation).

\section{Correlation between APD, LCH disease extension and DI}

Considering patients with complete evaluation, an ED was found in $73.7 \%$ of patients with MS-LCH and $63.1 \%$ patients with MS-LCH, but this difference was not significant $(P=0.07)$. Twenty-four of the 32 patients with DI (75\%) had at least one APD. Among the 31 patients without DI, eight had at least one APD: six in the subgroup

Table 3 Frequency of pituitary and hypothalamic abnormalities at the magnetic resonance imaging (MRI) of patients with endocrine dysfunction.

\begin{tabular}{|c|c|c|}
\hline & \multicolumn{2}{|c|}{$\%$ of patients $(n / N)$} \\
\hline & Adulthood & Childhood \\
\hline \multicolumn{3}{|l|}{ Pituitary gland size } \\
\hline Normal & $80(16 / 20)$ & $84.2(16 / 19)$ \\
\hline Increased & $10(2 / 20)$ & 0 \\
\hline Decreased & $10(2 / 20)$ & $15.8(3 / 19)$ \\
\hline \multicolumn{3}{|l|}{ Thickness of the pituitary stalk } \\
\hline Normal & $75(15 / 20)$ & $68.4(13 / 19)$ \\
\hline Increased & $20(4 / 20)$ & $15.8(3 / 19)$ \\
\hline Decreased & $5(1 / 20)$ & $15.8(3 / 19)$ \\
\hline \multicolumn{3}{|l|}{ Hypothalamic region } \\
\hline Infiltrated & $5(1 / 20)$ & $15.8(3 / 19)$ \\
\hline Non-infiltrated & $95(19 / 20)$ & $84.2(16 / 19)$ \\
\hline $\begin{array}{l}\text { Absence of the physiological } \\
\text { bright spot of the posterior } \\
\text { pituitary }\end{array}$ & $50(10 / 20)$ & $54.6(12 / 19)$ \\
\hline
\end{tabular}

of completely evaluated patients (15.8\%) and two in the others (8\%).

\section{Imaging}

Twelve of the 61 patients who underwent a pituitary MRI showed a visible infiltrative lesion of the pituitary region or stalk (Table 3$)$. Ten of them $(83.3 \%)$ had pituitary deficiencies. The hypothalamic region was infiltrated in $9.6 \%$ of patients (6 of 61 ). Four patients with unsuspected endocrine deficiencies that were detected for the first time on screening had MRI abnormalities.

An absence of the physiological T1 bright spot in the posterior pituitary was found in $36.1 \%$ of patients, all of whom had DI. Nine patients with DI still had a visible physiological T1 bright spot in the posterior pituitary.

\section{Bone evaluations}

We found no abnormality in calcium metabolism, except in 1 of 62 assessed patients with moderately low calcium levels and $83.9 \%$ of patients (26 of 31 ) with low vitamin D levels.

Thirty-one patients (mean age $=36$ years) underwent a BMD assessment by DEXA. Four of them were postmenopausal women and we found osteoporosis and osteopenia in one case each (these two patients had gonadotropin deficiency and a history of corticotherapy). There were no men aged 50 and older among the patients who underwent a BMD assessment.

Among the 27 nonmenopausal women and men younger than age 50 years who underwent a BMD assessment, 4 (14.8\%) had a Z-score below the expected range for age (one gonadotropin deficiency and two other after corticotherapy).

\section{Evolution}

Thirty-four patients (54\%, $15 \mathrm{AO}$ and $19 \mathrm{CO})$ required endocrine treatments.

Follow-up data were available for 58 patients $(20 \mathrm{CO}$ and 38 AO patients).

The mean follow-up time was $52.1 \pm 43.5$ months. Forty-eight patients underwent two endocrinological evaluations, and 35 patients underwent at least three assessments. The mean time between the first and the second evaluations and between the second and the third evaluations was respectively 1.3 and 2.7 years. Most of the pituitary deficiencies were permanent and some 
Table 4 Follow-up data of 58 patients with LCH and endocrine dysfunction.

\begin{tabular}{|c|c|c|c|c|c|c|}
\hline \multirow[b]{2}{*}{ Endocrine dysfunctions } & \multicolumn{3}{|c|}{ 2nd evaluation, $n$} & \multicolumn{3}{|c|}{ 3rd evaluation, $n$} \\
\hline & Disparition & Stable & New occurrence & Disparition & Stable & New occurrence \\
\hline Hyperprolactinemia & 3 & 5 & 0 & 1 & 4 & 4 \\
\hline Gonadotropin deficiency & 2 & 14 & 2 & 3 & 13 & 0 \\
\hline GH deficiency & 1 & 1 & 1 & NA & NA & NA \\
\hline Corticotropin deficiency & 1 & 7 & 2 & 0 & 5 & 1 \\
\hline Thyrotropin deficiency & 0 & 10 & 1 & 1 & 9 & 1 \\
\hline Diabetes insipidus & 0 & 32 & 0 & 0 & 32 & 0 \\
\hline
\end{tabular}

Mean time between the first and the second evaluation and between the second and the third evaluation: 1.3 and 2.7 years respectively. $\mathrm{GH}$, growth hormone; NA, not available.

that were not present at the first evaluation appeared progressively (Table 4 ).

\section{Discussion}

We report here a cohort of 63 consecutive patients with LCH who underwent endocrinological evaluations of pituitary, gonadal, adrenal and thyroid function. This study may have certain data limitations, such as the crosssectional design that does not allow for a longitudinal evaluation to examine exactly how ED evolved over time. Moreover, for the $\mathrm{CO} \mathrm{LCH}$ patients, we only included their data from our hospital. It is also possible that the 17 patients seen in neurology and excluded to this study could have had undiagnosed pituitary deficits. Finally, this study has other limitations that are a possible paucity of auxological and clinical data and difficulty in performing diagnosis of osteoporosis in young people.
Nevertheless, this study provides the first nearexhaustive investigation of endocrine and metabolic manifestations in LCH in a large cohort study.

$\mathrm{ED}$ was more prevalent in the $\mathrm{CO}$ forms than the AO forms. As previously reported, posterior pituitary dysfunction is a common endocrinological manifestation of $\mathrm{LCH}$, and $\mathrm{DI}$ is usually the first endocrine manifestation $(9,10,26,27,28,29,30)$. DI was the first endocrinological manifestation in $2.1 \%$ of $\mathrm{CO}$ patients in the French national LCH registry, but evaluations were not done systematically (31).

In our study, DI reached a prevalence of $55.3 \%$ in those with complete evaluation, and was similar to the one found in another recent study in a small population of adult pulmonary LCH patients with complete endocrine evaluations (10) but higher than the 30\% described in previous studies $(32,33)$, even when considering our subgroup of incompletely evaluated. This prevalence has been described to possibly reach $40 \%$ in patients with MS-LCH or $94 \%$ in the presence of other pituitary

Table 5 Recommendations for endocrine assessment and surveillance protocol in patients with LCH.

\begin{tabular}{ll}
\hline Pituitary & $\begin{array}{c}\text { Search for signs of anterior } \\
\text { pituitary deficits } \\
24-h \text { diuresis and water intake }\end{array}$
\end{tabular}

Gonads

Thyroid Search for a goiter and nodules Adrenal glands Search for signs of adrenal deficiency

\section{Morphological evaluation}

Pituitary MRI

24-h diuresis and water intake

Follow-up Every year
Thyroid sonography if clinical anomalies Adrenal CT scan

At any time if clinical or biological abnormalities

\begin{tabular}{l} 
Biological evaluation \\
\hline FSH, LH, E2 (women)/total \\
testosterone (men) \\
PRL \\
TSH, FT4 \\
IGF-I, GH under ITT \\
ACTH, cortisol under ITT or after \\
Synacthen test \\
Natremia and urinary osmolarity \\
FSH, LH, E2 (women), total \\
testosterone (men) \\
TSH, FT4 \\
ACTH, cortisol under ITT or after \\
Synacthen test \\
Renin, aldosterone \\
Every 3 years or at any time if clinical \\
abnormalities
\end{tabular}

ACTH, adrenocorticotropin; CT, computed tomography; E2, estradiol; FSH, follicle-stimulating hormone; FT4, free T4; GH, growth hormone, IGF-1, insulin-like growth factor-1; ITT, insulin tolerance test; LH, luteinizing hormone; MRI, magnetic resonance imaging; PRL, prolactin. 
deficiencies $(9,32,34)$, but in our study, there was no difference between SS-LCH and MS-LCH. Our prevalence was also more than the approximately 30\% reported in Erdheim Chester Disease (ECD), which is another histiocytic infiltrative disorder (7), even when a complete assessment was done systematically $(35,36)$. Our high prevalence was also attributable to $\mathrm{CO} \mathrm{LCH}$ in which almost three quarters of the patients had DI. One previous study of $70 \mathrm{CO}$ LCH patients found a 10-year cumulative incidence of DI of $20 \%$ (37).

As shown in this study, the absence of the physiological bright spot in the posterior pituitary is common in patients with DI and could be idiopathic or secondary to ECD or LCH $(34,35,38,39)$. For the patients with DI who still had a visible bright spot, it is likely that, depending on the conclusion of the neuroradiologist, the fat of the bony posterior wall of the sella turcica was falsely considered as the posterior pituitary bright spot. The second most common MRI abnormality is infundibular or pituitary stalk thickening $(31,38,39)$, but a normal pituitary MRI scan is not sufficient to rule out pituitary impairment. We did not find any neurodegenerative complications but pituitary gland abnormalities are a known risk factor (40).

The prevalence of APD in our two subgroups was also higher than the $8.7-33 \%$ reported previously in $\mathrm{LCH}$ or $\operatorname{ECD}(10,11,29,34,35,41,42)$, but very few studies have reported patients with a complete evaluation, which means that the prevalence of some deficiencies is probably underestimated. Our results suggest, contrary to recommendations $(1,2)$, that a complete hypothalamopituitary evaluation should be performed in all $\mathrm{LCH}$ patients, especially as $15.8 \%$ of our patients in the subgroup of completely evaluated and $12 \%$ in the second group had ED but they had no suspected endocrine manifestation before evaluation. APD is almost never associated with DI. Older age at the diagnosis of LCH or the presence of low risk clinical forms and fewer reactivation episodes seem to be the main predictors of a higher risk of developing APD when DI is already diagnosed (43).

The most common APD was GHD, followed by gonadotropin deficiency, hyperprolactinemia and thyrotropin deficiency in our two subgroups. Our findings are similar to those in the LCH and ECD literature $(9,10$, 29). But we cannot discard that GH deficiency has been probably overdiagnosed especially in the four obese adult patients in whom it was isolated or in children due to the lack of a confirmatory testing and auxological data. As previously observed, the pediatric guidelines recommend against reliance on GH provocative test results as the sole diagnostic criterion of GHD (44).
As found in other LCH and ECD studies $(10,35)$, the prolactin levels were moderately elevated, which can be attributed to pituitary stalk infiltration (1).

All of our patients with corticotropin deficiency reported a history of corticosteroid treatment, and we thus considered that they were deficient because of the treatment rather than the LCH.

We found no primary hypothyroidism (other than autoimmune hypothyroidism), but thyroid involvement is known to be involved in $\operatorname{LCH}(29,45,46,47)$.

The skeletal status of our population was difficult to ascertain on the basis of BMD alone because of the young age of our patients and because we did not systematically perform an active research for vertebral fractures (48). But it is known that this population has multiple risk factors of osteoporosis (proinflammatory cytokines, APD and hormonal replacement, and corticosteroid therapy, noncondensing bone lesions).

As described in other studies of patients with $\mathrm{LCH}$ or ECD, EDs can appear progressively during follow-up and generally are definitive $(9,35,37,42)$. It is thus important that all LCH patients be monitored regularly using established endocrine investigational protocols to detect further pituitary hormone deficiencies or metabolic alterations.

The prevalence of the BRAF V600E mutation in LCH ranges from 38 to $60 \%(49,50,51)$. This frequency was probably low because this test was performed only in a few patients.

In summary, we have confirmed that endocrine manifestations are extremely frequent in a large cohort of LCH patients who were evaluated systematically. Thus, we recommend a complete endocrine evaluation in each LCH patient and further regular monitoring.

Our recommendations for the endocrine assessment and monitoring protocol in patients with $\mathrm{LCH}$ are presented in Table 5.

\section{Declaration of interest}

The authors declare that there is no conflict of interest that could be perceived as prejudicing the impartiality of this study.

\section{Funding}

This research did not receive any specific grant from any funding agency in the public, commercial or non-profit sector.

\section{Acknowledgements}

The authors would like to thank Brigitte Delemer, Michel Polak and Juliane Leger for referring LCH patients to us for follow-up in our department, 
Monique Leban for performing the hormonal assays and Jérôme Dulon for managing the histiocytosis database.

\section{References}

1 Girschikofsky M, Arico M, Castillo D, Chu A, Doberauer C, Fichter J, Haroche J, Kaltsas GA, Makras P, Marzano AV et al. Management of adult patients with Langerhans cell histiocytosis: recommendations from an expert panel on behalf of Euro-Histio-Net. Orphanet Journal of Rare Diseases 20138 72. (https://doi.org/10.1186/1750-1172-8-72)

2 Haupt R, Minkov M, Astigarraga I, Schäfer E, Nanduri V, Jubran R, Egeler RM, Janka G, Micic D, Rodriguez-Galindo C et al. Langerhans cell histiocytosis (LCH): guidelines for diagnosis, clinical work-up, and treatment for patients till the age of 18 years. Pediatric Blood and Cancer 201360 175-184. (https://doi.org/10.1002/pbc.24367)

3 Berres M-L, Merad M \& Allen CE. Progress in understanding the pathogenesis of langerhans cell histiocytosis: back to histiocytosis X? British Journal of Haematology 2015169 3-13. (https://doi. org/10.1111/bjh.13247)

4 Laurencikas E, Gavhed D, Stålemark H, van't Hooft I, Prayer D, Grois N \& Henter J-I. Incidence and pattern of radiological central nervous system Langerhans cell histiocytosis in children: a population based study. Pediatric Blood and Cancer 201156 250-257. (https://doi.org/10.1002/pbc.22791)

5 Emile JF, Charlotte F, Chassagne-Clement C, Copin MC, Fraitag S, Mokhtari K \& Moreau A. Classification histologique et altérations moléculaires des histiocytoses. Presse Médicale 201746 46-54. (https://doi.org/10.1016/j.lpm.2016.01.016)

6 Vassallo R, Harari S \& Tazi A. Current understanding and management of pulmonary Langerhans cell histiocytosis. Thorax 2017 72 937-945. (https://doi.org/10.1136/thoraxjnl-2017-210125)

7 Emile JF, Abla O, Fraitag S, Horne A, Haroche J, Donadieu J, RequenaCaballero L, Jordan MB, Abdel-Wahab O, Allen CE et al. Revised classification of histiocytoses and neoplasms of the macrophagedendritic cell lineages. Blood 2016127 2672-2681. (https://doi. org/10.1182/blood-2016-01-690636)

8 Gadner H, Minkov M, Grois N, Potschger U, Thiem E, Arico M, Astigarraga I, Braier J, Donadieu J, Henter JI et al. Therapy prolongation improves outcome in multisystem Langerhans cell histiocytosis. Blood 2013121 5006-5014. (https://doi.org/10.1182/ blood-2012-09-455774)

9 Makras P, Alexandraki KI, Chrousos GP, Grossman AB \& Kaltsas GA. Endocrine manifestations in Langerhans cell histiocytosis. Trends in Endocrinology and Metabolism 200718 252-257. (https://doi. org/10.1016/j.tem.2007.06.003)

10 Montefusco L, Harari S, Elia D, Rossi A, Specchia C, Torre O, Adda G $\&$ Arosio M. Endocrine and metabolic assessment in adults with Langerhans cell histiocytosis. European Journal of Internal Medicine 201851 61-67. (https://doi.org/10.1016/j.ejim.2017.11.011)

11 Rigaud C, Barkaoui MA, Thomas C, Bertrand Y, Lambilliotte A, Miron J, Aladjidi N, Plat G, Jeziorski E, Galambrun C et al. Langerhans cell histiocytosis: therapeutic strategy and outcome in a 30-year nationwide cohort of 1478 patients under 18 years of age. British Journal of Haematology 2016174 887-898. (https://doi. org/10.1111/bjh.14140)

12 Garrahy A, Moran C \& Thompson CJ. Diagnosis and management of central diabetes insipidus in adults. Clinical Endocrinology 201990 23-30. (https://doi.org/10.1111/cen.13866)

13 Fleseriu M, Hashim IA, Karavitaki N, Melmed S, Murad MH, Salvatori R \& Samuels MH. Hormonal replacement in hypopituitarism in adults: an Endocrine Society clinical practice guideline. Journal of Clinical Endocrinology and Metabolism 2016101 3888-3921. (https://doi.org/10.1210/jc.2016-2118)

14 Chahal J \& Schlechte J. Hyperprolactinemia. Pituitary 200811 141-146. (https://doi.org/10.1007/s11102-008-0107-5)
15 Chitale A, Musonda P, McGregor AM \& Dhatariya KK. Determining the utility of the 60 min cortisol measurement in the short synacthen test. Clinical Endocrinology 201379 14-19. (https://doi. org/10.1111/j.1365-2265.2012.04478.x)

16 Bornstein SR, Allolio B, Arlt W, Barthel A, Don-Wauchope A, Hammer GD, Husebye ES, Merke DP, Murad MH, Stratakis CA et al. Diagnosis and treatment of primary adrenal insufficiency: an Endocrine Society clinical practice guideline. Journal of Clinical Endocrinology and Metabolism 2016101 364-389. (https://doi. org/10.1210/jc.2015-1710)

17 Molitch ME, Clemmons DR, Malozowski S, Merriam GR, Vance ML \& Endocrine Society. Evaluation and treatment of adult growth hormone deficiency: an Endocrine Society clinical practice guideline. Journal of Clinical Endocrinology and Metabolism 201196 1587-1609. (https://doi.org/10.1210/jc.2011-0179)

18 Ho KKY \& 2007 GH Deficiency Consensus Workshop Participants. Consensus guidelines for the diagnosis and treatment of adults with GH deficiency II: a statement of the GH Research Society in association with the European Society for Pediatric Endocrinology, Lawson Wilkins Society, European Society of Endocrinology, Japan Endocrine Society, and Endocrine Society of Australia. European Journal of Endocrinology 2007157 695-700. (https://doi.org/10.1530/ EJE-07-0631)

19 Yuen KCJ. Growth hormone stimulation tests in assessing adult growth hormone deficiency. In Endotext. Eds KR Feingold, B Anawalt, A Boyce, G Chrousos, K Dungan, A Grossman, JM Hershman, G Kaltsas, C Koch, P Kopp et al. South Dartmouth, MA, USA: MDText. com, Inc., 2000. (available at http://www.ncbi.nlm.nih.gov/books/ NBK395585/)

20 Bozzola M \& Meazza C. Growth hormone deficiency: diagnosis and therapy in children. In Restricted Growth - Clinical, Genetic and Molecular Aspects. Ed Cardenas-Aguayo M del C. London, UK: InTech, 2016. (https://doi.org/10.5772/64803)

21 Wagner IV, Paetzold C, Gausche R, Vogel M, Koerner A, Thiery J, Arsene CG, Henrion A, Guettler B, Keller E et al. Clinical evidencebased cutoff limits for GH stimulation tests in children with a backup of results with reference to mass spectrometry. European Journal of Endocrinology 2014171 389-397. (https://doi.org/10.1530/EJE-140165)

22 Clayton PE, Cuneo RC, Juul A, Monson JP, Shalet SM, Tauber M \& European Society of Paediatric Endocrinology. Consensus statement on the management of the GH-treated adolescent in the transition to adult care. European Journal of Endocrinology 2005152 165-170. (https://doi.org/10.1530/eje.1.01829)

23 Society GR. Consensus guidelines for the diagnosis and treatment of growth hormone (GH) deficiency in childhood and adolescence: summary statement of the GH Research Society. Journal of Clinical Endocrinology and Metabolism 200085 3990-3993. (https://doi. org/10.1210/jcem.85.11.6984)

24 Alberti C, Chevenne D, Mercat I, Josserand E, Armoogum-Boizeau P, Tichet J \& Leger J. Serum concentrations of insulin-like growth factor (IGF)-1 and IGF binding protein-3 (IGFBP-3), IGF-1/IGFBP-3 ratio, and markers of bone turnover: reference values for French children and adolescents and z-score comparability with other references. Clinical Chemistry 201157 1424-1435. (https://doi.org/10.1373/ clinchem.2011.169466)

25 Schousboe JT, Shepherd JA, Bilezikian JP \& Baim S. Executive summary of the 2013 International Society for clinical densitometry position development conference on bone densitometry. Journal of Clinical Densitometry 201316 455-466. (https://doi.org/10.1016/j. jocd.2013.08.004)

26 Makras P \& Kaltsas G. Langerhans cell histiocytosis and pituitary function. Endocrine 201548 728-729. (https://doi.org/10.1007/ s12020-014-0497-2)

27 García Gallo MS, Martínez MP, Abalovich MS, Gutiérrez S \& Guitelman MA. Endocrine manifestations of Langerhans cell 
histiocytosis diagnosed in adults. Pituitary 201013 298-303. (https:// doi.org/10.1007/s11102-010-0233-8)

28 Imashuku S. Management of adult Langerhans cell histiocytosis based on the characteristic clinical features. World Journal of Hematology 20132 89-98. (https://doi.org/10.5315/wjh.v2.i3.89)

29 Donadieu J, Rolon MA, Thomas C, Brugieres L, Plantaz D, François Emile JF, Frappaz D, David M, Brauner R, Genereau T et al. Endocrine involvement in pediatric-onset Langerhans' cell histiocytosis: a population-based study. Journal of Pediatrics 2004144 344-350. (https://doi.org/10.1016/j.jpeds.2003.12.030)

30 Tazi A, Lorillon G, Haroche J, Neel A, Dominique S, Aouba A, Bouaziz JD, de Margerie-Melon C, Bugnet E, Cottin V et al. Vinblastine chemotherapy in adult patients with langerhans cell histiocytosis: a multicenter retrospective study. Orphanet Journal of Rare Diseases 201712 95. (https://doi.org/10.1186/s13023-0170651-z)

31 Marchand I, Barkaoui MA, Garel C, Polak M, Donadieu J \& Writing Committee. Central diabetes insipidus as the inaugural manifestation of Langerhans cell histiocytosis: natural history and medical evaluation of 26 children and adolescents. Journal of Clinical Endocrinology and Metabolism 201196 E1352-E1360. (https://doi. org/10.1210/jc.2011-0513)

32 Grois N, Pötschger U, Prosch H, Minkov M, Arico M, Braier J, Henter JI, Janka-Schaub G, Ladisch S, Ritter J et al. Risk factors for diabetes insipidus in langerhans cell histiocytosis. Pediatric Blood and Cancer 200646 228-233. (https://doi.org/10.1002/pbc.20425)

33 Aricò M, Girschikofsky M, Généreau T, Klersy C, McClain K, Grois N, Emile JF, Lukina E, De Juli E \& Danesino C. Langerhans cell histiocytosis in adults. Report from the International Registry of the Histiocyte Society. European Journal of Cancer 200339 2341-2348. (https://doi.org/10.1016/S0959-8049(03)00672-5)

34 Kaltsas GA, Powles TB, Evanson J, Plowman PN, Drinkwater JE, Jenkins PJ, Monson JP, Besser GM \& Grossman AB. Hypothalamopituitary abnormalities in adult patients with Langerhans cell histiocytosis: clinical, endocrinological, and radiological features and response to treatment. Journal of Clinical Endocrinology and Metabolism 200085 1370-1376. (https://doi.org/10.1210/jcem.85.4.6501)

35 Courtillot C, Laugier Robiolle S, Cohen Aubart F, Leban M, RenardPenna R, Drier A, Charlotte F, Amoura Z, Touraine P \& Haroche J. Endocrine manifestations in a monocentric cohort of 64 patients with Erdheim-Chester disease. Journal of Clinical Endocrinology and Metabolism 2016101 305-313. (https://doi.org/10.1210/jc.20153357)

36 Pertuiset E, Laredo JD, Lioté F, Wassef M, Jagueux M \& Kuntz D. Erdheim-Chester disease: report of a case, review of the literature and discussion of the relation to Langerhans-cell histiocytosis. Revue $d u$ Rhumatisme 199360 601-609.

37 Chow TW, Leung WK, Cheng FWT, Kumta SM, Chu WCW, Lee V, Shing MMK \& Li CK. Late outcomes in children with Langerhans cell histiocytosis. Archives of Disease in Childhood 2017102 830-835. (https://doi.org/10.1136/archdischild-2016-312185)

38 Varan A, Cila A, Akyuz C, Kale G, Kutluk T \& Buyukpamukcu M. Radiological evaluation of patients with pituitary Langerhans cell histiocytosis at diagnosis and at follow-up. Pediatric Hematology and Oncology 200825 567-574. (https://doi. org/10.1080/08880010802237112)

39 Kurtulmus N, Mert M, Tanakol R \& Yarman S. The pituitary gland in patients with Langerhans cell histiocytosis: a clinical and radiological evaluation. Endocrine 201548 949-956. (https://doi.org/10.1007/ s12020-014-0408-6)
40 Héritier S, Barkaoui MA, Miron J, Thomas C, Moshous D, Lambilliotte A, Mazingue F, Kebaili K, Jeziorski E, Plat G et al. Incidence and risk factors for clinical neurodegenerative Langerhans cell histiocytosis: a longitudinal cohort study. British Journal of Haematology 2018183 608-617. (https://doi.org/10.1111/bjh.15577)

41 Haupt R, Nanduri V, Calevo MG, Bernstrand C, Braier JL, Broadbent V, Rey G, McClain KL, Janka-Schaub G \& Egeler RM. Permanent consequences in Langerhans cell histiocytosis patients: a pilot study from the Histiocyte Society? Late Effects Study Group. Pediatric Blood and Cancer 200442 438-444. (https://doi.org/10.1002/ pbc.20021)

42 Makras P, Samara C, Antoniou M, Zetos A, Papadogias D, Nikolakopoulou Z, Andreakos E, Toloumis G, Kontogeorgos G, Piaditis $\mathrm{G}$ et al. Evolving radiological features of hypothalamopituitary lesions in adult patients with Langerhans cell histiocytosis (LCH). Neuroradiology 200648 37-44. (https://doi.org/10.1007/ s00234-005-0011-x)

43 Vaiani E, Malossetti C, Vega LM, Zubizarreta P, Braier J \& Belgorosky A. Predictor variables of developing anterior pituitary deficiencies in a group of paediatric patients with central diabetes insipidus and Langerhans cell histiocytosis. Hormone Research in Paediatrics 201787 51-57. (https://doi.org/10.1159/000452996)

44 Grimberg A, DiVall SA, Polychronakos C, Allen DB, Cohen LE, Quintos JB, Rossi WC, Feudtner C, Murad MH \& Drug and Therapeutics Committee and Ethics Committee of the Pediatric Endocrine Society. Guidelines for growth hormone and insulinlike growth factor-I treatment in children and adolescents: growth hormone deficiency, idiopathic short stature, and primary insulinlike growth factor-I deficiency. Hormone Research in Paediatrics 2016 86 361-397. (https://doi.org/10.1159/000452150)

45 Lollar K, Farrag TY, Cao D, Niparko J \& Tufano RP. Langerhans cell histiocytosis of the thyroid gland. American Journal of Otolaryngology 200829 201-204. (https://doi.org/10.1016/j. amjoto.2007.05.004)

46 Behrens RJ, Levi AW, Westra WH, Dutta D \& Cooper DS. Langerhans cell histiocytosis of the thyroid: a report of two cases and review of the literature. Thyroid 200111 697-705. (https://doi. org/10.1089/105072501750362781)

47 Foulet-Roge A, Josselin N, Guyetant S, Gardet JJ, Bescancon A, SaintAndre JP \& Fabiani B. Incidental Langerhans cell histiocytosis of thyroid: case report and review of the literature. Endocrine Pathology 200213 227-233. (https://doi.org/10.1385/EP:13:3:227)

48 Mazziotti G, Frara S \& Giustina A. Pituitary diseases and bone. Endocrine Reviews 201839 440-488. (https://doi.org/10.1210/er.201800005)

49 Satoh T, Smith A, Sarde A, Lu HC, Mian S, Trouillet C, Mufti G, Emile JF, Fraternali F, Donadieu J et al. B-RAF mutant alleles associated with Langerhans cell histiocytosis, a granulomatous pediatric disease. PLoS ONE 20127 e33891. (https://doi.org/10.1371/ journal.pone.0033891)

50 Sahm F, Capper D, Preusser M, Meyer J, Stenzinger A, Lasitschka F, Berghoff AS, Habel A, Schneider M, Kulozik A et al. BRAFV600E mutant protein is expressed in cells of variable maturation in Langerhans cell histiocytosis. Blood 2012120 e28-e34. (https://doi. org/10.1182/blood-2012-06-429597)

51 Badalian-Very G, Vergilio JA, Degar BA, MacConaill LE, Brandner B, Calicchio ML, Kuo FC, Ligon AH, Stevenson KE, Kehoe SM et al. Recurrent BRAF mutations in Langerhans cell histiocytosis. Blood 2010116 1919-1923. (https://doi.org/10.1182/blood-2010-04279083)

Received 18 March 2019

Revised version received 19 June 2019

Accepted 3 July 2019 